\title{
Assessment of Cocoa Producers' Children Nutritional Status in the Nawa Region, Côte d'Ivoire
}

\author{
Agbo Adouko Edith ${ }^{1, *}$, Kouamé Christophe ${ }^{2}$, N'Doua N'Doua Denos ${ }^{1}$, Kouassi Allegra ${ }^{2}$, Brou Kouakou ${ }^{1}$ \\ ${ }^{1}$ Food Science and Technology Department, Nangui Abrogoua University, Abidjan, Côte d'Ivoire \\ ${ }^{2}$ World Agroforestry Centre, Abidjan, Côte d'Ivoire \\ *Corresponding author: edipagbo@gmail.com
}

\begin{abstract}
Foods are important as they provide nutrients for human being. However, in the world and particularly in Africa, several people suffer of under nutrition due to a lack of proteins, energy and micronutrients. Malnutrition affects the agricultural sector unfortunately. A survey was conducted in 2015 among cocoa producers' households from 11 localities in the Nawa region which is the largest cocoa production region of Côte d'Ivoire. Anthropometric measurements were collected on 218 children between 6 and 59 months old and the data were used to calculate the following indices used to assess nutritional status: weight-for-height, height-for-age and weight-for-age. The results showed that global acute malnutrition prevalence was $17.5 \%$ (95\% Confidence interval (CI): $13.0,23.1 \%)$, with $12.4 \%$ (95\% CI: 8.7, $17.5 \%$ ) for the moderate form and 5.1\% (95\% CI: $2.9,8.8 \%)$ for the severe one. Global chronic malnutrition prevalence was about 39\% (95\% CI: 32.8, 45.6\%) and the moderate and the severe forms were respectively $22 \%$ (95\% CI: $17,28 \%$ ) and $17 \%$ (95\% CI: 12.6, $22.5 \%)$. Underweight prevalence was $25.2 \%$ (95\% CI: $19.9,31.4 \%)$ with $17 \%$ (95\% CI: $12.6,22.5 \%)$ for moderate underweight and $8.3 \%$ (95\% CI: $5.3,12.7 \%)$ for severe underweight. There were any statistical difference between boys and girls. The distribution curves of index are offset from the reference curve for all malnutrition forms. Children among 6-17 months were generally affected by acute malnutrition while chronic malnutrition concerned children aged from 18 to 53 months. Cocoa producers' children are affected by malnutrition and the prevalence is important, indicating a possible lack of food diversification.
\end{abstract}

Keywords: malnutrition, anthropometric measurements, cocoa producers, children, Nawa region

Cite This Article: Agbo Adouko Edith, Kouamé Christophe, N'Doua N'Doua Denos, Kouassi Allegra, and Brou Kouakou, "Assessment of Cocoa Producers' Children Nutritional Status in the Nawa Region, Côte d'Ivoire." Journal of Food and Nutrition Research, vol. 5, no. 8 (2017): 606-613. doi: 10.12691/jfnr-5-8-11.

\section{Introduction}

Malnutrition is a public health concern in many countries in Africa. It causes nutritional deficiencies (in proteins, energy, vitamins and minerals) and has consequences on people physical capacity and cognitive development [1]. In Côte d'Ivoire, the mortality rate of children under 5 was 108\%o in 2013 and an average of $33 \%$ of children was malnourished [2]. Moreover, the country has one of the highest rates of childhood stunting worldwide, an indicator for chronic malnutrition [3]. Indeed, the nutritional status of children below 60 months indicates that $27.3 \%$ of them suffered from stunting [4].

Côte d'Ivoire is the world's largest cocoa producer, contributing to $40 \%$ of the global supply. Most of this cocoa $(20 \%)$ is produced in the Nawa region located in the southwest of the country [5]. In this region, the promotion of cocoa, instead of food crops (during the 15 last years), in response to the demand for increasing cocoa productivity and yield, has caused a food crisis, resulting in the shortage of major food crops on the local markets [6]. Consequently, most households are in a situation of food insecurity and vulnerability with a prevalence rate of $21.5 \%$ [7]. This situation could favour malnutrition.
Many factors are involved in malnutrition causes: climatic seasons, food access and availability, population eating habits and choice [8,9]. Moreover, a recent mapping of malnutrition in the major cocoa producing areas of Côte d'Ivoire (including Western, Central-eastern, Southern and South-western regions) has revealed stunting rates varying from 25 to $34 \%$ [10]. As the Nawa region takes an important place in the economy of Côte d'Ivoire, there is a need to evaluate the nutritional status of the cocoa producers' children. This will reflect population food access and food diet. Anthropometric measurements and 24-hours recall interviews will be provided for children of some localities of the region in order to better manage children nutritional status.

\section{Material and Methods}

\subsection{The Nawa Region}

The study took place in the Nawa region, an agricultural region located in South-western Côte d'Ivoire (Figure 1). The survey was conducted in 11 localities particularly among cocoa producers' households in May 2015 (during the rainy season). In theses localities a MARS-ICRAF vision for change program on cocoa plantation rehabilitation and communities' development is implemented. 


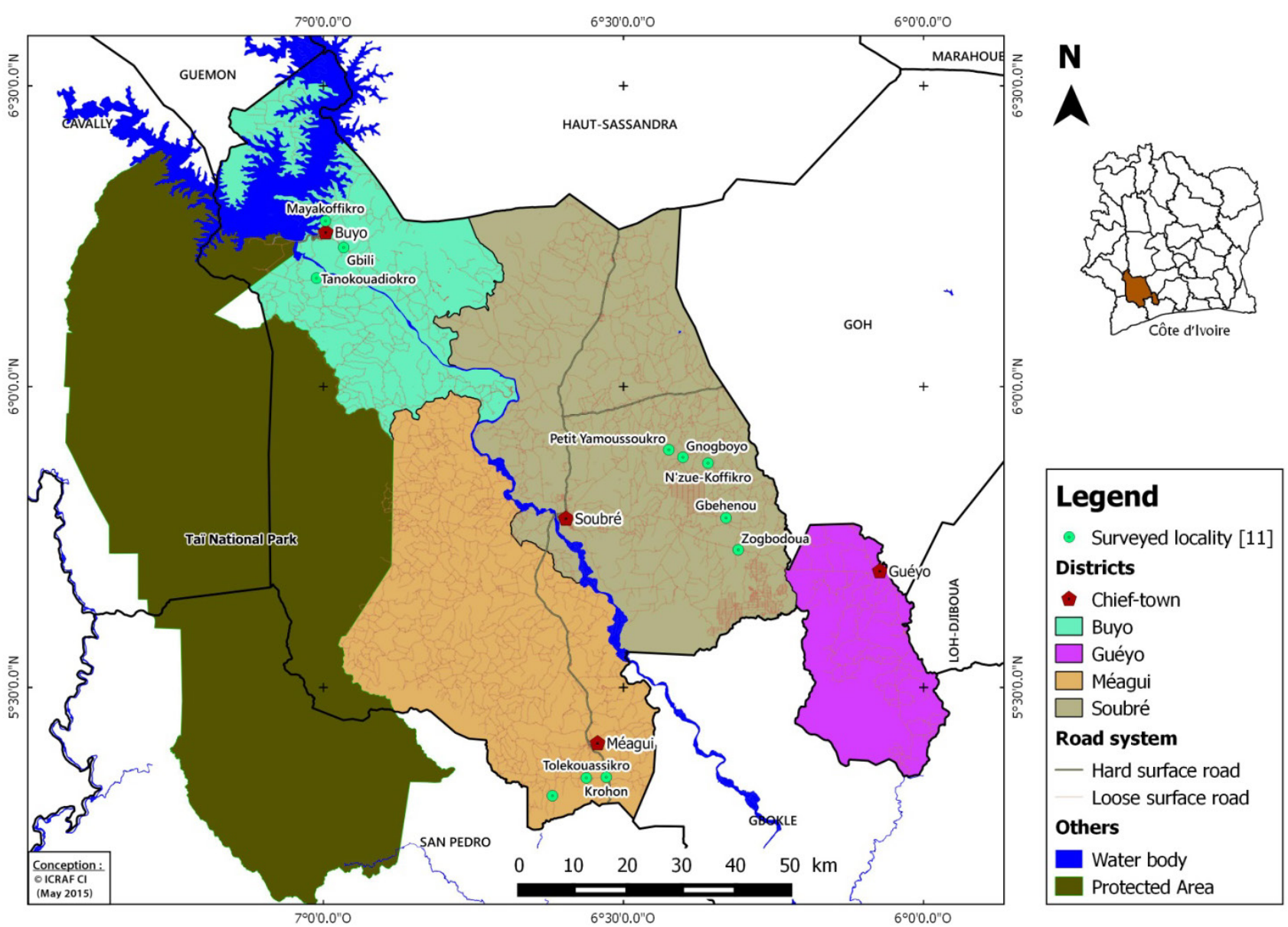

Figure 1. The Nawa region map with the 11 surveyed localities

\subsection{Sampling}

The localities choice was based on a previous survey conducted on production, consumption and eating habits of cocoa households in 2014 [11]. This survey has taken into account 38 localities and has revealed that in 11 of them, chronic malnutrition prevalence was critical (Prevalence $>40 \%$ ) [12] (Table 1). The present study was then conducted in these eleven localities in order to understand such prevalence.

Table 1. Previous chronic malnutrition prevalence in 2014

\begin{tabular}{lc}
\hline & Chronic malnutrition prevalence (\%) \\
\hline Krohon & 72.4 \\
Tolekouassikro & 69.2 \\
Gnangomiankro & 80 \\
Gnogboyo & 64.5 \\
Gbili & 44.2 \\
Mayakoffikro & 45 \\
Tanokouadiokro & 54.5 \\
Gbehenou & 50 \\
Zogbodoua & 30.8 \\
Petit-Yamoussoukro & 61.5 \\
Nzuekoffikro & 65.2 \\
\hline
\end{tabular}

Households sample size (212) was calculated according to the equation (1) with the expected malnutrition prevalence of the NAWA region (27.1\%) [13].

$$
n=N \times P
$$

n: sample size

$\mathrm{N}$ : enumerated households

$\mathrm{P}$ : malnutrition prevalence in the studied region

For a total of 783 cocoa producers in the 11 localities, 212 households were surveyed. The households were the same of that of the previous studies.

Children aged between 6 and 59 months were selected in the surveyed households, so that, in one household, only one child, of the mother surveyed, among those aged between 6 and 59 months has been taken into account. Preferably, the child who had participated to the previous survey was chosen. If he no longer met the criteria (older than 59 months), he has been replaced by the one who followed him. This child was previously designate by her mother. An exception was made for households with twins. In this case, both children participated to the survey because they have the same age and it was not interesting to choose one of them as they are twins. Children aged have been got by consulting birth certificate or child Health-Passport.

Thus, anthropometric measurements have been taken to 218 children, including 06 twins. Table 2 shows the sample repartition by village. 
Table 2. Repartition of households and children surveyed by localities

\begin{tabular}{|c|c|c|c|}
\hline Administrative unit & Localities & Number of Households & Number of Children \\
\hline \multirow{4}{*}{ MEAGUI } & KROHON & 29 & 29 \\
\hline & TOLEKOUASSIKRO & 13 & 13 \\
\hline & GNANGOMIANKRO & 10 & 10 \\
\hline & GNOGBOYO & 30 & 31 \\
\hline \multirow{3}{*}{ BUYO } & GBILI & 39 & 43 \\
\hline & MAYAKOFFIKRO & 20 & 20 \\
\hline & TANOKOUADIOKRO & 10 & 11 \\
\hline \multirow{2}{*}{ OKROUYO } & GBEHENOU & 12 & 12 \\
\hline & ZOGBODOUA & 13 & 13 \\
\hline \multirow{3}{*}{ LILIYO } & PETIT YAMOUSSOUKRO & 13 & 13 \\
\hline & N'ZUEKOFFIKRO & 23 & 23 \\
\hline & TOTAL & 212 & 218 \\
\hline
\end{tabular}

\subsection{Selection Criteria}

\subsubsection{Inclusion Criteria}

- Cocoa producers' households

- Only one child aged between 6 and 59 months for each household except in six households where twins were considered. This age limit was chosen because it defined the childhood period and also because children food diversification begins at 6 months [14]

- Be present during the survey

- Have parents' acceptance

\subsubsection{Exclusion Criteria}

- Non cocoa producers' households

- Children 0-5 months aged and children older than 59 months

- Sick children

- Refusal of parents

\subsection{Anthropometric Measurements}

Anthropometric measurements were taken on children by professional caregivers who were trained before data collection. Anthropometric measurements (weight and height) were determined using standard measurement tools. Children over 2 years were weighted directly on digital weighing scales (SEKA, precision $100 \mathrm{~g}$ ). For children less than 2 years, their weight was determined by the method of double weighing: mothers first and secondly, mothers and their children. On the other hand, the height of children over 2 years was measured to the nearest $\mathrm{mm}$ using a wall height gauge (graduated in $\mathrm{cm}$ ) in the standing position. Children less than two years heights were measured in the supine position using UNICEF-like fathom wood [15].

\subsection{Dietary Diversity Score}

A 24-hours recall interview with mothers was used to enumerate children food diet [16]. The data were collected by trained enumerators. The 24-hours recall allowed determining children dietary diversity score according to the indicators for assessing infant and young child feeding practices [17].

\subsection{Statistical Analysis}

Anthropometric data were analyzed with ENA 2011 (Emergency Nutrition Assessment) software and the nutritional status of children was assessed using the usual index based on combinations of weight, height, and age [12]: weight for height $(\mathrm{W} / \mathrm{H})$, height- for-age $(\mathrm{H} / \mathrm{A})$ and weight- for-age (W/A).

SPSS Statistics for Windows, version 22.0, was used to compare data. A one-way ANOVA was performed to compare the nutrition indices between localities. When a significant difference was observed, the means were separated using Duncan test $(\mathrm{p} \leq 0.05)$.

\subsection{Ethical Standards Disclosure}

This study has been approved by the National Ethical and Research Committee of Côte d'Ivoire (030/MSLS/CNER-dkn). In each village, authorities were contacted and informed before enumerators and caregivers' arrival. Free and written informed consent to participate the survey was obtained from each household head for interviewing mothers and for taking anthropometric measurements on children.

\section{Results}

\subsection{Children Overall Nutritional Status}

The overall children cocoa producers' malnutrition prevalence in the 11 localities was about $17.5 \%$ (95\% CI: $13.0,23.1 \%$ ) for global acute malnutrition with $12.4 \%$ (95\% CI: $8.7,17.5 \%)$ for the moderate form and 5.1\% $(95 \%$ CI: $2.9,8.8 \%$ ) for the severe one. Global chronic malnutrition prevalence was about 39\% (95\% CI: 32.8, 45.6\%). Moderate and severe forms were respectively $22 \%(95 \% \mathrm{CI}: 17$, $28 \%$ ) and $17 \%$ (95\% CI: 12.6, 22.5\%). Underweight prevalence was $25.2 \%$ (95\% CI: $19.9,31.4 \%$ ) with $17 \%$ (95\% CI: 12.6, 22.5\%) for moderate underweight and $8.3 \%$ (95\% CI: 5.3, 12.7\%) for severe underweight (Figure 2). 


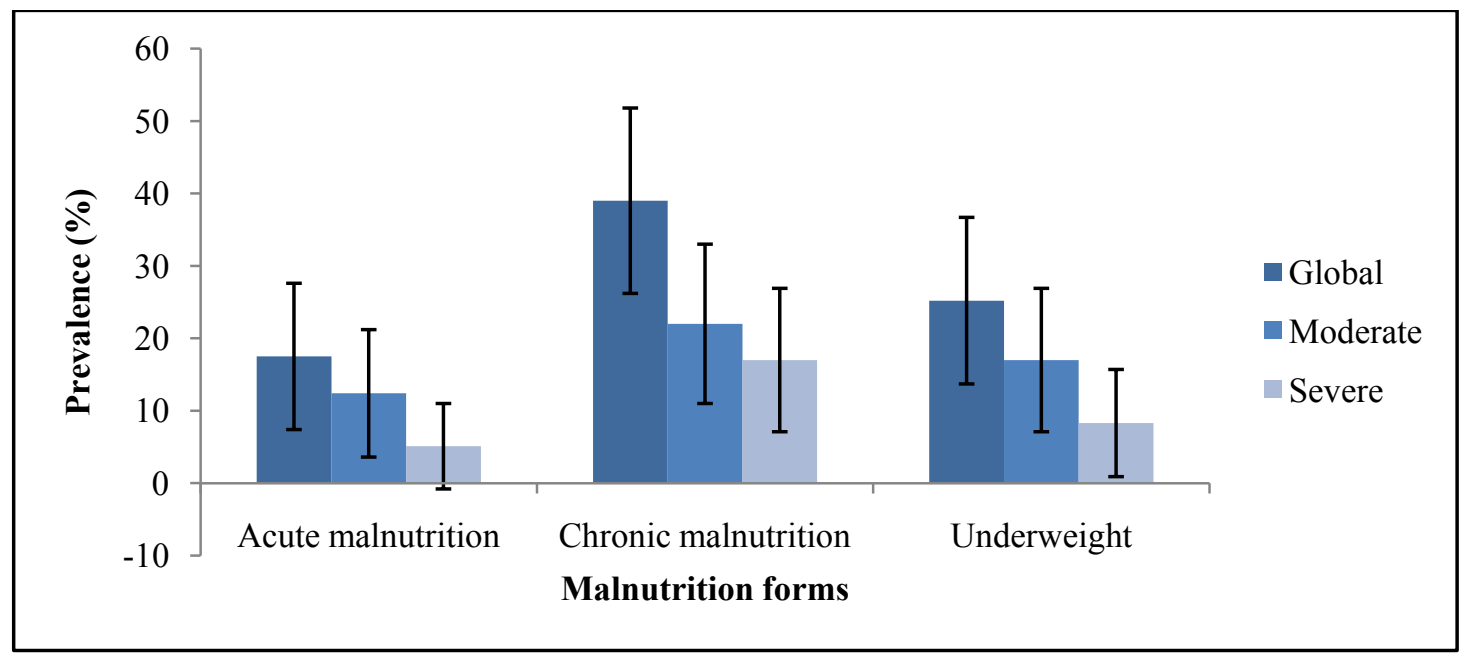

Figure 2. Cocoa producers' children general malnutrition prevalence

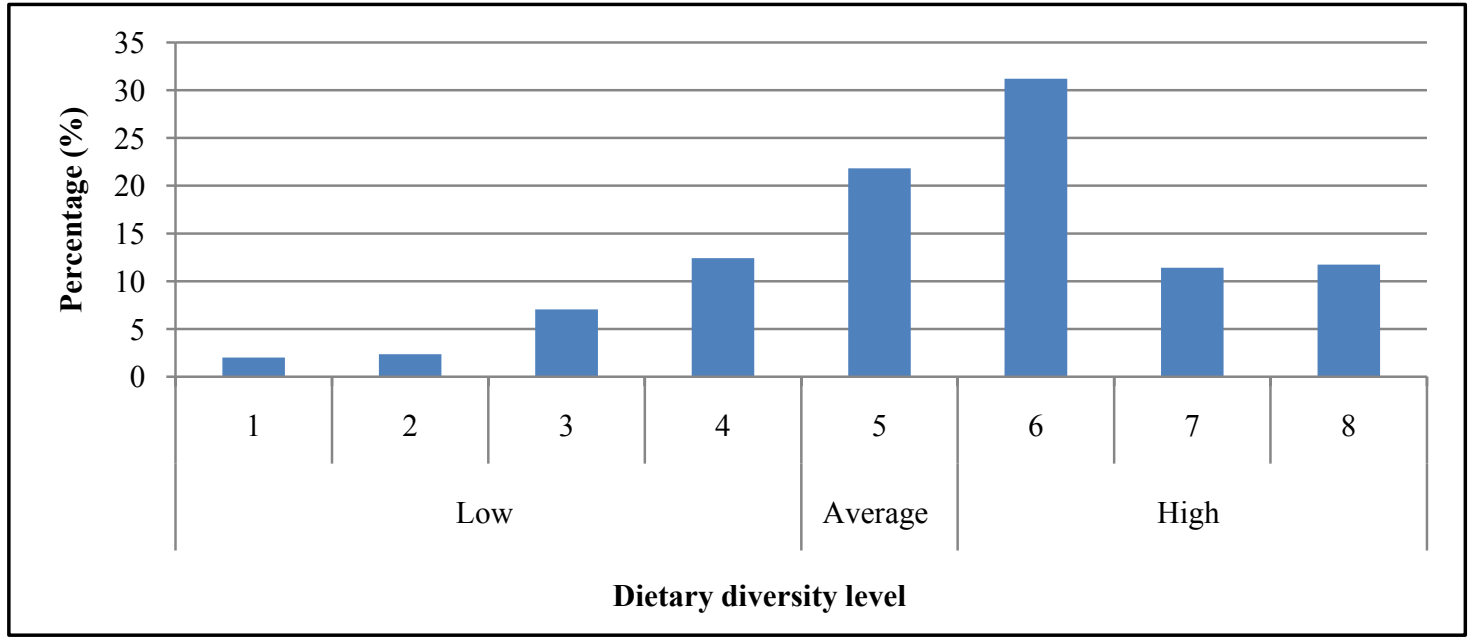

Figure 3. Children dietary diversity score

\subsection{Children Dietary Diversity}

The 24-hours recall showed that children staple food was made of tubers and cereals. They also ate fish $(61.41 \%)$, fruits $(49.33 \%)$, carotene rich vegetables $(38.25 \%)$ and nuts $(14.43 \%)$. The average dietary diversity score was 5.30 . Around $23.83 \%$ of children had low food diversity (consuming 4 food groups), 21.81\% average food diversity (consuming 5 food groups) and 54.36\% high food diversity (consuming over 6 food groups) (Figure 3).

\subsection{Variation of Children Malnutrition Prevalence between Localities}

Underweight, acute and chronic malnutrition prevalence in the studied localities was showed in Table 3. For acute malnutrition Tanokouadiokro had the highest prevalence $45.5 \% \quad(95 \%$ CI: $21.3,72 \%)$ which was statistically different of that of Krohon 3.4\% (95\% CI: 0.6, 17.2\%), Tolekouassikro 7.7\% (95\% CI: 1.4, 33.3\%), Gnangomiankro $10 \%$ (95\% CI: 1.8, 40.4\%) and Mayakoffikro 10\% (95\% CI: $2.8,30.1 \%)$.

Chronic malnutrition prevalence was low at Nzuekoffikro 13.0\% (95\% CI: 4.5, 32.1\%). This prevalence differed significantly from that of Tolekouassikro $46.2 \%$ (95\% CI:
23.2, 70.9\%), Petit-Yamoussoukro 53.8\% (95\% CI: 29.1, $76.6 \%$ ) and Mayakoffikro 65\% (95\% CI: 43.3, 81.9\%). There was any statistical difference between the others localities.

Underweight prevalence of Nzuekoffikro $(8.7 \%$ (95\% CI: $2.4,26.8 \%)$ ) and that of Tanokouadiokro $(45.5 \%(95 \%$ CI: $21.3,72 \%)$ ) differed statistically. But they didn't differ to that of the others localities.

Table 3. Global malnutrition prevalence by localities

\begin{tabular}{lccc}
\hline & \multicolumn{3}{c}{ Malnutrition prevalence (\%) } \\
\cline { 2 - 4 } & Acute & Chronic & Underweight \\
\hline Krohon & $3.4^{\mathrm{a}}$ & $41.4^{\mathrm{abc}}$ & $41.4^{\mathrm{abc}}$ \\
Tolekouassikro & $7.7^{\mathrm{a}}$ & $46.2^{\mathrm{bc}}$ & $46.2^{\mathrm{bc}}$ \\
Gnangomiankro & $10^{\mathrm{a}}$ & $30^{\mathrm{abc}}$ & $30^{\mathrm{abc}}$ \\
Gnogboyo & $22.6^{\mathrm{ab}}$ & $38.7^{\mathrm{abc}}$ & $38.7^{\mathrm{abc}}$ \\
Gbili & $21.4^{\mathrm{ab}}$ & $44.2^{\mathrm{abc}}$ & $44.2^{\mathrm{abc}}$ \\
Mayakoffikro & $10^{\mathrm{a}}$ & $65^{\mathrm{c}}$ & $65^{\mathrm{c}}$ \\
Tanokouadiokro & $45.5^{\mathrm{b}}$ & $18.2^{\mathrm{ab}}$ & $18.2^{\mathrm{ab}}$ \\
Gbehenou & $16.7^{\mathrm{ab}}$ & $33.3^{\mathrm{abc}}$ & $33.3^{\mathrm{abc}}$ \\
Zogbodoua & $15.4^{\mathrm{ab}}$ & $30.8^{\mathrm{abc}}$ & $30.8^{\mathrm{abc}}$ \\
Petit-Yamoussoukro & $23.1^{\mathrm{ab}}$ & $53.8^{\mathrm{c}}$ & $53.8^{\mathrm{c}}$ \\
Nzuekoffikro & $21.7^{\mathrm{ab}}$ & $13^{\mathrm{a}}$ & $13^{\mathrm{a}}$ \\
\hline
\end{tabular}




\subsection{Malnutrition Prevalence per Gender}

There is no significant difference between boys and girls for all malnutrition forms.

Global acute malnutrition prevalence among boys is about $14.1 \%$ (95\% CI: 9.1, 21.1\%) with 10.9\% (95\% CI: $6.6,17.5 \%)$ for the moderate form and $3.1 \%(95 \% \mathrm{CI}: 1.2$,
$7.8 \%$ ) for the severe form (Table 4). For girls, the prevalence is around 20.4\% (95\% CI: 14, 28.7\%) with $14.2 \%$ (95\% CI: 8.9, 21.8\%) and 6.2\% (95\% CI: 3, 12.2\%) for moderate and severe forms respectively (Table 5). The distribution curves of weight-for-height index for girls and boys are below the reference curve and the average index is $-0.44 \pm 1.57 \mathrm{z}$-scores (Figure 4 ).

Table 4. Boys' malnutrition prevalence

\begin{tabular}{cccc}
\hline & \multicolumn{3}{c}{ Malnutrition forms } \\
\cline { 2 - 5 } & Global (\%) & Moderate (\%) & Severe (\%) \\
\hline W / H & $14.1(95 \% \mathrm{CI}: 9.1,21.1)$ & $10.9(95 \% \mathrm{CI}: 6.6,17.5)$ & $3.1(95 \% \mathrm{CI}: 1.2,7.8)$ \\
H / A & $42.6(95 \% \mathrm{CI}: 34.4,51.3)$ & $24(95 \% \mathrm{CI}: 17.5,32.1)$ & $18.6(95 \% \mathrm{CI}: 12.8,26.2)$ \\
W / A & $24(95 \% \mathrm{CI}: 17.5,32.1)$ & $15.5(95 \% \mathrm{CI}: 10.3,22.7)$ & $8.5(95 \% \mathrm{CI}: 4.8,14.6)$ \\
\hline
\end{tabular}

W/H: Weight-for-Height; H/A: Height-for-Age; W/A: Weight-for-Age.

Table 5. Girls' malnutrition prevalence

\begin{tabular}{|c|c|c|c|}
\hline & \multicolumn{3}{|c|}{ Malnutrition forms } \\
\hline & Global (\%) & Moderate (\%) & Severe $(\%)$ \\
\hline $\mathrm{W} / \mathrm{H}$ & $20.4(95 \%$ CI : $14,28.7)$ & $14.2(95 \% \mathrm{CI}: 8.9,21.8)$ & $6.2(95 \%$ CI : $3,12.2)$ \\
\hline $\mathrm{H} / \mathrm{A}$ & $34.5(95 \%$ CI : $26.4,43.7)$ & $20.4(95 \%$ CI : $14,28.7)$ & $14.2(95 \% \mathrm{CI}: 8.9,21.8)$ \\
\hline $\mathrm{W} / \mathrm{A}$ & $24.8(95 \%$ CI : $17.7,33.5)$ & $16.8(95 \%$ CI : $11,24.8)$ & $8(95 \% \mathrm{CI}: 4.2,14.4)$ \\
\hline
\end{tabular}

W/H: Weight-for-Height; H/A: Height-for-Age; W/A: Weight-for-Age.

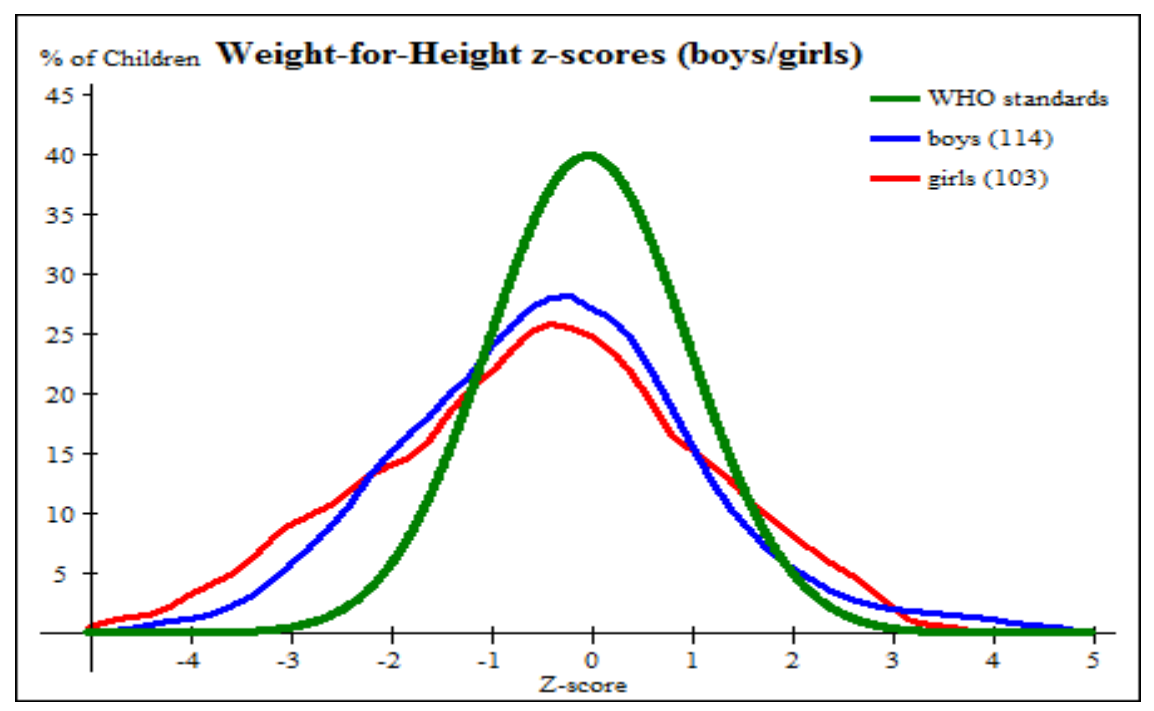

Figure 4. Distribution of Weight-for-Height index according to sex regarding population reference WHO 2006

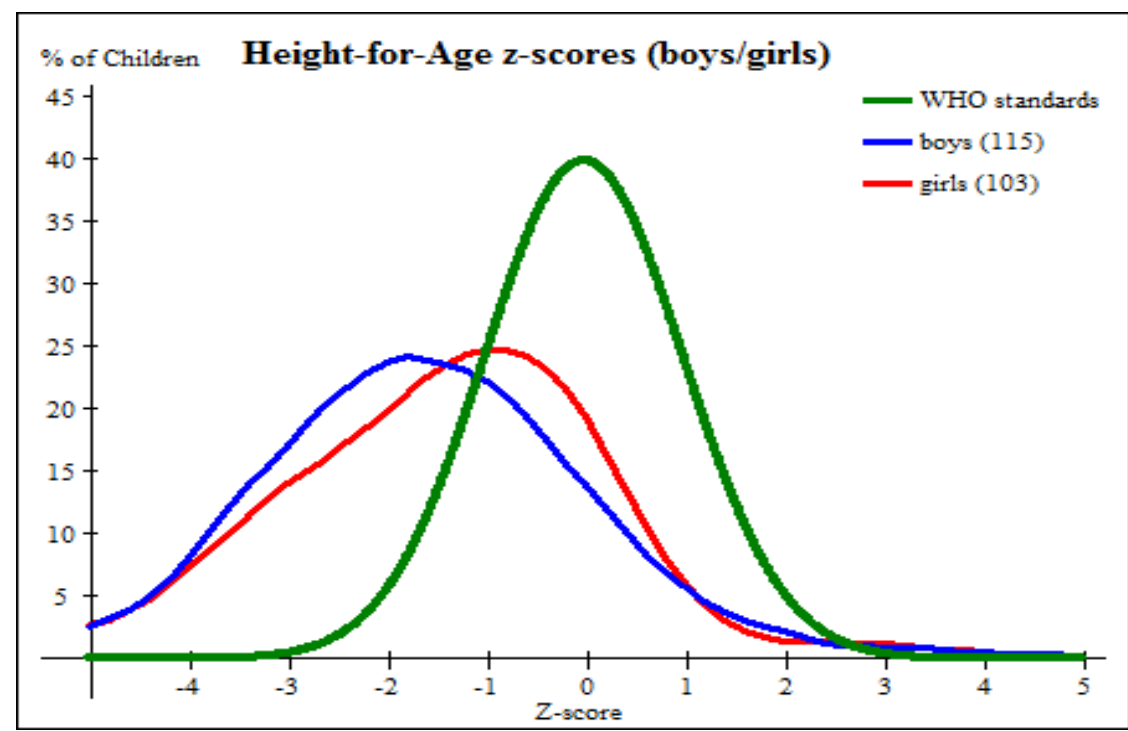

Figure 5. Distribution of Height-for-Age index according to sex regarding population reference WHO 2006 


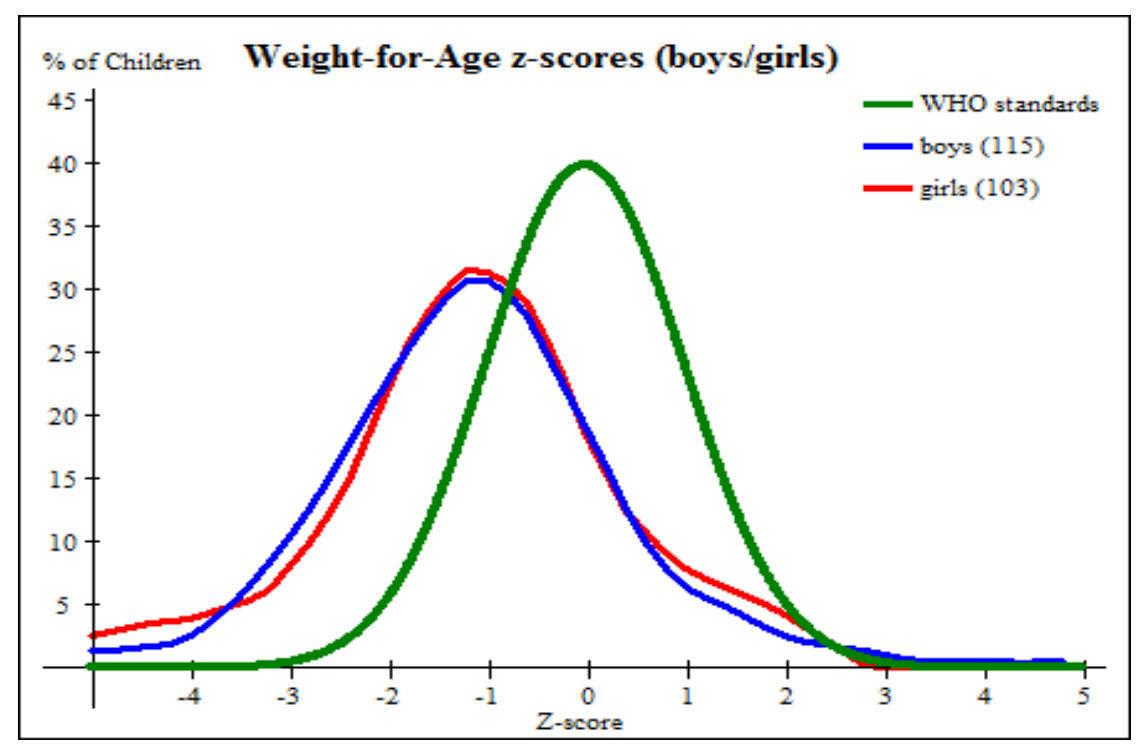

Figure 6. Distribution of Weight-for-Age index according to sex regarding population reference WHO 2006

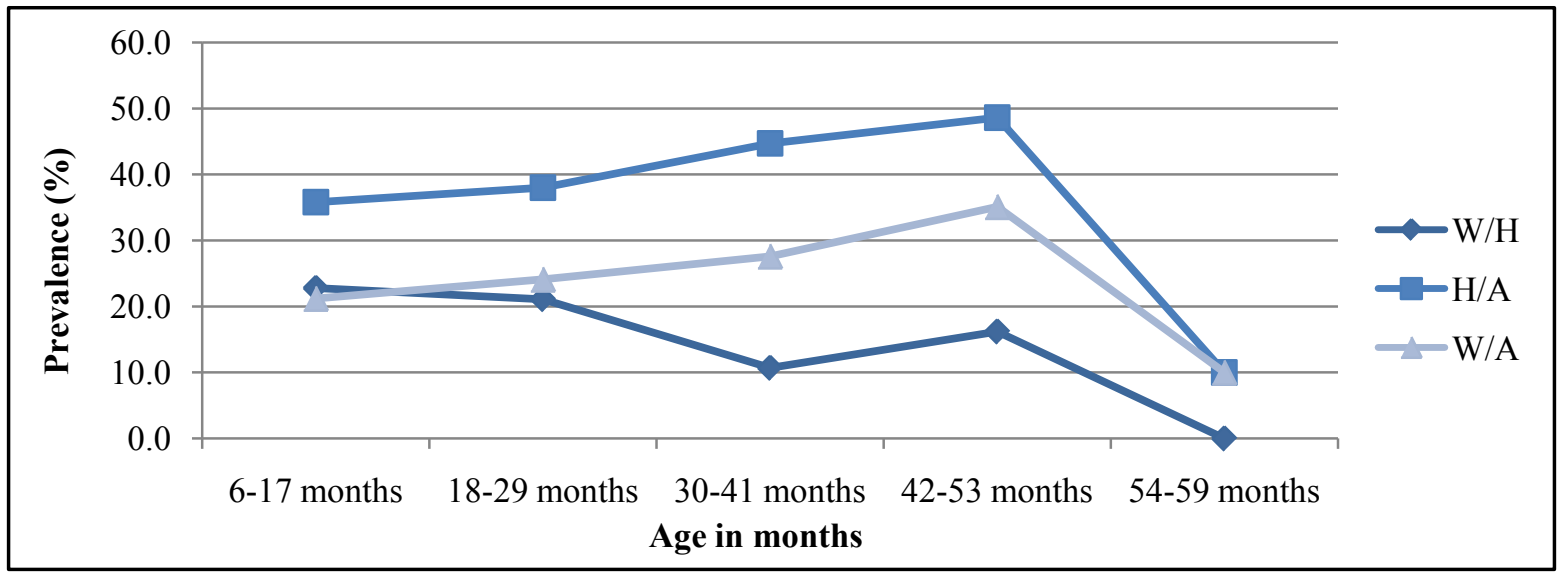

Figure 7. Evolution of malnutrition prevalence according to age groups (W/H: Weight-for-Height; H/A: Height-for-Age; W/A: Weight-for-Age)

For boys, the global chronic malnutrition prevalence was around $42.6 \%$ (95\% CI: 34.4, 51.3\%). The moderate form was about $24 \%(95 \%$ CI: $17.5,32.1 \%)$ and the severe one was $18.6 \%$ (95\% CI: 12.8, 26.2\%) (Table 4). The global chronic malnutrition among girls was $34.5 \%$ (95\% CI: $26.4,43.7 \%$ ) with $20.4 \%$ (95\% CI: $14,28.7 \%$ ) for moderate form and $14.2 \%$ (95\% CI: $8.9,21.8 \%$ ) for severe form (Table 5). The distribution curves of boys and girls height-for-age index were offset from the reference curve and the average index was $-1.53 \pm 1.82 \mathrm{z}$-scores (Figure 5).

Underweight global prevalence was $24 \%$ (95\% CI: 17.5 , $32.1 \%)$ for boys. The moderate and severe forms were 15.5\% (95\% CI: $10.3,22.7 \%)$ and $8.5 \%$ (95\% CI: 4.8 , $14.6 \%$ ) respectively (Table 4). For girls, underweight global prevalence was $24.8 \%$ (95\% CI: $17.7,33.5 \%$ ) with $16.8 \%$ (95\% CI: $11,24.8 \%$ ) for the moderate form and $8 \%$ (95\% CI: 402, 14.4\%) for the severe form (Table 5). The distribution curves of boys and girls weight-for-age index were offset from the reference curve and the average index was $-1.16 \pm 1.52 \mathrm{z}$-scores (Figure 6).

\subsection{Malnutrition Prevalence per Age Groups}

Children have been classified in 5 age groups: 6-17 months, 18-29 months, 30-41 months, $42-53$ months and
54-59 months (Software ENA, 2011). There was any statistical difference between age group for all malnutrition forms. For wasting (acute malnutrition), the most affected aged group is $6-17$ months with $22.8 \%$ for the global form, $16.7 \%$ for the moderate form and $6.1 \%$ for the severe form. Children among 54-59 months were not affected by acute malnutrition. The malnutrition age evolution curves of chronic malnutrition and underweight had the same appearance. For stunting (chronic malnutrition) the most affected groups were $30-41$ and $42-53$ months with a respective global prevalence of $44.7 \%$ and $48.6 \%$. For children among $30-41$ months $21.3 \%$ present a moderate chronic malnutrition form against $23.4 \%$ for the severe form. The moderate stunting prevalence of children among $42-53$ months was about $27 \%$ and the severe prevalence was $21.6 \%$. Underweight global prevalence is high among children aged from 42 to 53 months (35.1\%). The moderate form concerned $29.7 \%$ of children and the severe one $5.4 \%$ (Figure 7 ).

\section{Discussion}

This study had revealed malnutrition prevalence among children in cocoa communities. According to WHO criteria [12] the acute malnutrition prevalence was critical 
and the chronic malnutrition and underweight prevalence were serious. All these malnutrition forms prevalence were also higher than for others children of the Nawa region. Indeed, regional acute malnutrition prevalence is $6.3 \%$. The chronic malnutrition prevalence is $27.1 \%$ and the underweight prevalence is $14.4 \%$ [4]. Acute malnutrition reflected a recent emaciation and the high prevalence could be a consequence of insufficient food intake and/or a high incidence of infectious diseases [12]. Indeed, the study had been made in rainy season which favoured malaria and parasite diseases. These diseases could affect children nutrients intake [18]. Chronic malnutrition and underweight (which reflected both acute malnutrition and chronic malnutrition) were due to situation where children height and weight were insufficient given to their age. They high prevalence could be due to growth retardation as a result of poor diets or recurrent infections and illness $[12,19]$. It could also be due to inadequate agricultural policies, power governance and producers' food choices and eating habits [9]. In addition, instruction level could be implicated, while, in cocoa production zone, most people were never at school $(56.4 \%)$, principally women [5]. So, they are not really aware of infant nutrition such as diversification stage [8].

Dietary diversity score was high, indicating amelioration in children alimentation. Indeed, the previous dietary diversity score (2014) was 3.62 with respectively $37.42 \%$, $34.38 \%$ and $28.2 \%$ of children in low, average and high diversity score [11]. This situation could be due to seasonal food availability because this study had been conducted in rainy season and the previous one in dry season. It could also have an impact on malnutrition prevalence [8].

The prevalence of acute malnutrition is acceptable only in Krohon, precarious in Tolekouassikro, in Gnangomiankro and in Mayakoffikro [12]. However, it is critical in the others villages. Furthermore, this prevalence is higher than that indicated in Koutiala in Mali [20] which is about 12\% and than that of Selingue in Mali (8.6\%) [21]. But it is lower than that of Imo state in Nigeria which is $23.6 \%$ [22]. Chronic malnutrition prevalence used to decrease in 8 localities in comparison to the previous prevalence. But the prevalence is always high. This suggested that stunting is strongly marked in the region and could indicated inadequate dietary intake and episodes of infection periods during children growth. This prevalence is "critical" for most villages. In addition, this prevalence is higher than $29 \%$ which was the stunting rate among cocoa producers of the region in 2012 [10]. It is also higher than that of children in Burkina Faso and in Soudan for whom chronic malnutrition prevalence was respectively $38.1 \%$ and $20.9 \%$ [23,24].

All malnutrition forms prevalence didn't differ statistically between boys and girls. But, for chronic malnutrition boys were more affected than girls. This phenomenon has been also observed in others studies [24,25]. The fact that the distributions curves of index were offset from the reference curve indicate that malnutrition was more important among cocoa producers in the Nawa region.

Wasting (acute malnutrition) was high among young children (6-17 months) and used to decrease with age. This period corresponded to the beginning of weaning period [14]. It was a critical period because all mothers were not always aware of dietary diversification. They could introduce food early or later for their children or they could give only cereals or tubers without proteins sources like milk to their children [26]. All this could favour a lack of nutrients for children. Chronic malnutrition and underweight are more observed among children aged from 18 to 53 months. This is due, in part, to children refusal to eat familial food, fruits and vegetables [27]. All these factors contribute to long period of insufficient dietary and nutritional intake for the young child.

\section{Conclusion}

This study conducted in 11 villages in the Nawa region highlights under malnutrition among cocoa producers' communities. The prevalence of all malnutrition forms is higher than that of the region. However, in comparison to the previous year, this prevalence has decreased and the dietary diversity score has increased because of food availability in this period. This indicates food insecurity and food diversification problems in the region. It is therefore clear that immediate and urgent actions must be taken to address malnutrition in cocoa sector of Nawa region. One of these actions should be food diet and agriculture diversification with nutrients rich crops like leafy vegetables and tubers rich in carotene and women formation on nutrition and hygienic practices. This will ameliorate children dietary intake and contribute to overcome malnutrition.

\section{Acknowledgements}

The authors acknowledge the Agriculture for Nutrition and Health program and Mars Inc. for their implication in the survey. Thanks to the heads of communities, producers' households and their children.

\section{Statement of Competing Interests}

The authors have no competing interest in relation to their work.

\section{List of Abbreviations}

\section{CI: Confidence Interval.}

\section{References}

[1] El Hiuoi, M.., Soualem, A., Ahami, A.O.T., Aboussaleh, Y., Rusinek, S. and Dik, K., "Socio-demographic and anthropometric characteristics relative to the scholastic performance in a rural school of Kenitra (Morocco)", Anthropo, 17: 25-33. 2008.

[2] United Nations International Children's Emergency Fund, Annual report Côte d'Ivoire, UNICEF, Abidjan, 2013, 36.

[3] Bhutta, Z.A., Das, J.K., Rizvi, A., Galley, M.F., Walker, N., Horton, S., Webb, P., Lartey, A. and Black, R.E., "Maternal and Child Nutrition 2. The Lancet Nutrition Intervention Review Group and the Maternal and Child nutrition Study Group", Series, 2, 1-26, June 2013. 
[4] Ministry of agriculture, FAO and WHO, Thorough assessment of the food security of rural households in Côte d'Ivoire. Report. Abidjan, 2009, 79.

[5] Health Ministry in charge of fighting AIDS, National nutrition survey based on SMART methodology. Final report. Abidjan, 2011, 84.

[6] Assiri, A., Yoro, G., Deheuvels, O., Kebe, B.I., Keli, Z.J., Adiko, A. and Assa, A., "Les caractéristiques agronomiques des vergers de cacaoyer (Theobroma cacao L.) en Côte d'Ivoire", J Anim Plant Sci, 2: 55-66. 2009.

[7] Coulibaly, L., Evaluation of eating habits in V4C implementation area. ICRAF-CDI Community Development Research report. ICRAF-CDI, Abidjan, 2013, 21.

[8] Huong, L.T., Xuan, L.T.T., Phoung, L.H., Hugen, D.T.T. and Rocklv J., "Diet and nutritional status among children 24-59 months by seasons in a mountainous area of Northern Vietnam in 2012", Glob Health Action, 7, 9, December 2014.

[9] Food and Agriculture Organization, The state of food and agriculture. Report. Geneva: FAO, 2013, 114.

[10] De Vries, K., Mc Clafferty, B. and Van Dorp, M., Increasing cocoa productivity through improved nutrition - A call to action, Concept Brief. Global Alliance for Improved Nutrition. Wageningen University, 2012, 24.

[11] Agbo, E., Mahyao, A., Konan, A.D., Coulibaly, L., Kouassi, A., Kehlenbeck, K. and Kouamé, C., Production, consumption and nutrition survey in a cocoa farming area in the Nawa region. Report. ICRAF, Abidjan, 2014, 137.

[12] World Health Organization, Nutrition Landscape Information System (NLIS) country profile indicators: interpretation guide. WHO, Geneva, 2012, 50.

[13] Hellen Keller International and Programme Alimentaire Mondial. Baseline assessment of the nutritional status of children aged 6 to 59 months in rural regions of Maradi and Zinder. Report of 2 surveys. Niamey, 2005, 115.

[14] World Health Organization. Infant and young child feeding, Fact sheet. WHO, 342, 2016.

www.who.int/mediacentre/factsheet/fs342/en/[Accessed in January 2017]

[15] INSTAT, DN/DNS. Enquête nutritionnelle anthropométrique et de mortalité rétrospective, Report, Mali, 2013, 96.

[16] Kennedy, G., Ballard, T. and Dop M.C., Guideline for measuring household and individual dietary diversty. FAO, Rome, 2013, 53.
[17] World Health Organization. Indicators for assessing feeding practices of infants and young children. Geneva, 2009, 19.

[18] N'go, P.K., Azzaoui, F.Z., Ahami, A.O.T., Aboussaleh, Y., Lachheb, A. and Hamrani A., "Déterminants socioéconomiques, environnementaux et nutritionnels de l'échec scolaire: cas des enfants résidant en zone cacaoyère de Soubré (Côte d'Ivoire)". Antropo, 28: 63-70, 2012.

[19] Koné, M.B., Traoré, S., Brou, K., Agbo, E. and Gnakri, D., "Assessment of serum calcium, serum iron and nutritional status among under-five children in six municipalities of Abidjan district, Côte d'Ivoire", Int J Child Health Nutri, 3:139-147, 2014.

[20] Koné, J.M., Evaluation de l'état nutritionnel des enfants de 6-59 mois dans le cercle de Koutiala. Thèse de doctorat, Université de Bamako, 2011, 107.

[21] Dembélé, G., Connaissance et pratiques des mères par rapport à la nutrition et à la santé des enfants de 6-59 mois dans le district sanitaire de Selingue. Thèse de doctorat, Université de Bamako, 2010, 113.

[22] Duru, C. B., Oluoha, U. R., Uwakwe, K. A., Diwe, K. C., Merenu, I. A., Chigozie, I. O. and Iwu, A. C., "Prevalence and Sociodemographic Determinants of Malnutrition among UnderFive Children in Rural Communities in Imo State, Nigeria." American Journal of Public Health Research, 3 (6): 199-206. 2015.

[23] Loada, M., and Ouredraogo-Nikiema, L., Enquête nationale sur l'insécurité alimentaire et la malnutrition. Rapport final, Burkina Faso, 2009, 193.

[24] Faroug, B. M. A. and Nagah A. A. M., "Assessment of Nutritional Status in Endogeneous Children in Rural Area in Northern Sudan." American Journal of Food and Nutrition, 2 (4) : 63-65. 2014.

[25] Programme Alimentaire Mondial, Analyse Globale de la Sécurité Alimentaire, de la Nutrition et de la Vulnérabilité au Burundi. Burundi, Rapport, 2014, 158.

[26] Kouassi, K.A., Agbo, A.E., Gnahe, D.A., Gbogouri, G.A., Brou, K and Gnakri, D., "Comparaison des caractéristiques nutritionnelles et rhéologiques des bouillie sinfantiles préparées par les techniques de germination et de fermentation", Int J Biol Chem Sci, 9: 944-953, 2015.

[27] Arts-Rodas, D. And Benoît, D., "Feeding problems in infancy and early childhood: Identification and managements. Paediatr child Health, 3 (1): 21-27, 1998. 